\title{
Relationship between Waste with Ectoparasites and Endoparasites (Nematodes and Cestodes) in Rats
}

\author{
Hermansyah Mamonto ${ }^{1 *}$, Syamsuar Manyullei ${ }^{1}$, Firdaus Hamid ${ }^{2}$, Anwar Daud $^{1}$, Aminuddin Syam ${ }^{3}$, Agus \\ Birawida $^{1}$ \\ ${ }^{1}$ Department of Environmental Health, Faculty of Public Health, Hasanuddin University, Indonesia \\ ${ }^{2}$ Department of Microbiology, Faculty of Medicine, Hasanuddin University, Indonesia \\ ${ }^{3}$ Department of Nutrition, Faculty of Public Health, Hasanuddin University, Indonesia
}

\section{*Corresponding Author}

Hermansyah Mamonto

\author{
Article History \\ Received: 01.07.2020 \\ Accepted: 12.07 .2020 \\ Published: 16.07 .2020
}

\begin{abstract}
Rats act as a reservoir for various diseases that can be transmitted to humans such as Murine typhus, PES, helminthiasis, and leptospirosis. Therefore, the presence of these mice plays an important role in the epidemiology of disease transmission, because in addition to being a host mouse also acts as a reservoir for several diseases. The zoonotic disease originating from mice is caused by the presence of ectoparasites and endoparasites that live in mice. This study aims to determine the relationship between the presence of waste with ectoparasites and endoparasites in mice. This research is a quantitative study with a cross-sectional design. Data obtained by observing the type of rat, identification of ectoparasites and endoparasites, calculation of success traps, univariate analysis using Chi-square test to determine the relationship between the presence of waste with ectoparasites and endoparasites in mice. The results showed that of the 37 rats caught, $78 \%$ were Rattus norvegicus, $15 \%$ Suncus murinus, and 7\% Mus musculus. This study found $68 \%$ of rats infected with Xenopsylla cheopis ectoparasite type and $81 \%$ infected with endoparasites type from subclass nematode and Cestoda which are zoonotic which can increase the risk of infection in humans. From the test results, it was found that there is a relationship between the presence of waste with endoparasites (nematode and Cestoda) and there is no relationship between the presence of waste with ectoparasites in mice. Therefore, it is necessary to control the mouse regularly.
\end{abstract}

Keywords: Rats, Trash, Zoonosis, Ectoparasites, Endoparasites.

\section{INTRODUCTION}

Mice are easily infected by parasitic agents due to lifestyle, habitat, and direct contact with other mice. Therefore, they can be a major source of internal and external parasites for animals and humans [1].

In environments that do not meet health requirements, mice are present breeding and spreading. Viewed from the health aspect, this Rodentia needs to get more attention because it can act as a reservoir for various diseases that can be transmitted to humans (zoonoses) [2].

Many species of mice can have adverse effects such as being a plant pest and more alarming can transmit pathogens to humans. Rats are reservoirs for vector-borne pathogens such as Tick-borne encephalitis, Borrelia spp, PES, Murine typhus, helminthiasis, and leptospirosis. Many parasites and bacterial and viral pathogens are carried by mice and some of them can be transmitted to humans and cause zoonotic disease [3].

Rats are living things that are vulnerable to being infected by dangerous diseases because they like dirty environment. Setyaningrum [4] reports that almost all organs of rats have been infected by dangerous diseases, especially worm diseases. The zoonotic disease originating from mice is caused by the presence of ectoparasites and endoparasites

Copyright @ 2020: This is an open-access article distributed under the terms of the Creative Commons Attribution license which permits unrestricted use, distribution, and reproduction in any medium for non commercial use (NonCommercial, or CC-BY-NC) provided the original author and source are credited. 
that live in mice. Rodent endoparasites such as mice are vectors for many pathogenic microorganisms and can also act as important reservoirs for zoonoses [5].

Based on environmental aspects, the incidence of zoonoses is more common in tropical and subtropical countries with high rainfall. Environmental conditions in the area are very optimal for parasitic growth. Slums with poor sanitation are closely related to the incidence of helminthiasis and PES. This is caused by an increase in rat population thereby increasing the likelihood of contact between humans and infected animals [6].

Diseases transmitted by ectoparasites can be caused by infection with various disease agents from the group of viruses, rickettsia, bacteria, protozoa, and worms. The disease can be transmitted to humans directly by saliva, urine, and feces of rats or through bites from their ectoparasites (fleas, fleas, ticks, and mites) [7]. Therefore the recognition of mice and their ectoparasites is very important.

Transmission of helminthiasis can occur directly and indirectly. Direct transmission is caused by consuming water or food contaminated by worm eggs, while indirect transmission occurs through intermediaries of fleas, mosquitoes, etc. [8]. Based on several observations, found Angiostrongylus cantonensis which infects the human brain and causes meningoencephalitis [9]. Hymenolepis nana and Hymenolepis diminuta cause hymenolepiasis [10].

In 1991 - 1998 there were 245,375 people who died due to PES, of which 17.6\% occurred in East Java; 51.5\% in Central Java, and 30.9\% in West Java. The highest death rate occurred in 1934, 23,275 people died [11]. The spread of various infectious diseases that occur in Indonesia is mostly caused by the lack of attention to improving environmental health.

The infection of Hymenolepis diminuta and Hymenolepis nana in mice was carried out by Priyanto [12] in Banjarnegara Regency. In addition, Pramestuti et al. [13] also reported the presence of infections of several worm species found in rat heart organs in Kedung Pring Village, Kemranjen Subdistrict, and Beji Village Kedung Banteng Subdistrict, Banyumas Regency. Some helminthiases are spread by mice, namely Hymenolepiasis, Strobilocerkosis, and Meningocephalitis Disease.

Areas in South Sulawesi have a high risk of disease contamination due to rat contamination, which occurs in the Wajo area in the villages of Wiringpalannae and Mattirotappareng. This is seen from the environmental aspect. The intended environmental health risks include the use of surface water sources, namely rivers, a distance of water sources and physical quality of water that does not meet health requirements, the absence of SPAL (Sewerage Sewer), and the absence of household waste bins [14]. Opportunities for exposure to environmental health hazards are the habit of not washing hands with soap (CTPS) [15].

According to data obtained from the Antang Health Center [16], an increase in cases of typhus due to ectoparasites in the last 3 years (2016, 2017 and 2018) with widal examination increased by an average of 27\%. Based on these data it can be assumed that there are parasitic animals that carry disease. For this reason, it is necessary to know the relationship between the presence of waste with ectoparasites and endoparasites in mice at Sultan Hasanuddin International Airport and the settlements of residents of Antang Village.

\section{METHODS}

\section{Research design}

This research was conducted for 1 month, from February to March 2020. The type of research used was quantitative research with a cross-sectional design. Rat capture in this study consisted of two locations, namely Sultan Hasanuddin International Airport and in Ampang Village. Each location has 100 traps installed at various predetermined places, namely ST-PAP, MPH, Airport Authority Offices, BMKG (Meteorology Climatology and Geophysics Council), Cargo, Bazarnas, Makassar Class I KKP, AVSEC, Concordia Canteen and seven RWs in Antang Village.

\section{Population and Sample}

The population in this study were all rats in Sultan Hasanuddin International Airport and Antang Village. The sampling technique uses non-probability sampling, namely accidental sampling, which is accidental sampling by taking mice that happen to be caught in a mousetrap.

\section{Data collection}

Data collection methods used in this study were through observation or observation as well as through microscope examination, calculation of success traps, observation of the presence of waste, and identification of rat species. 


\section{Data analysis}

Analysis of the data used in this research is Univariate Analysis which is used to find out the description of the characteristics of research subjects, expressed in the form of tables and narratives to find out the proportions of each variable and Bivariate analysis. at the 0.05 confidence level and 95\% confidence interval $(\alpha=0.05)$ and the exact Fisher test was used to test the significance of the comparative hypothesis of two independent small samples for nominal data.

\section{RESULTS}

\section{Rat Type Identification}

From the results of a survey conducted at Sultan Hasanuddin International Airport, a total of 10 rats were obtained, while the results of trapping in Antang Village for four days totaled 27 rats were caught. During the study, there were no traps lost so as to facilitate the process of catching mice.

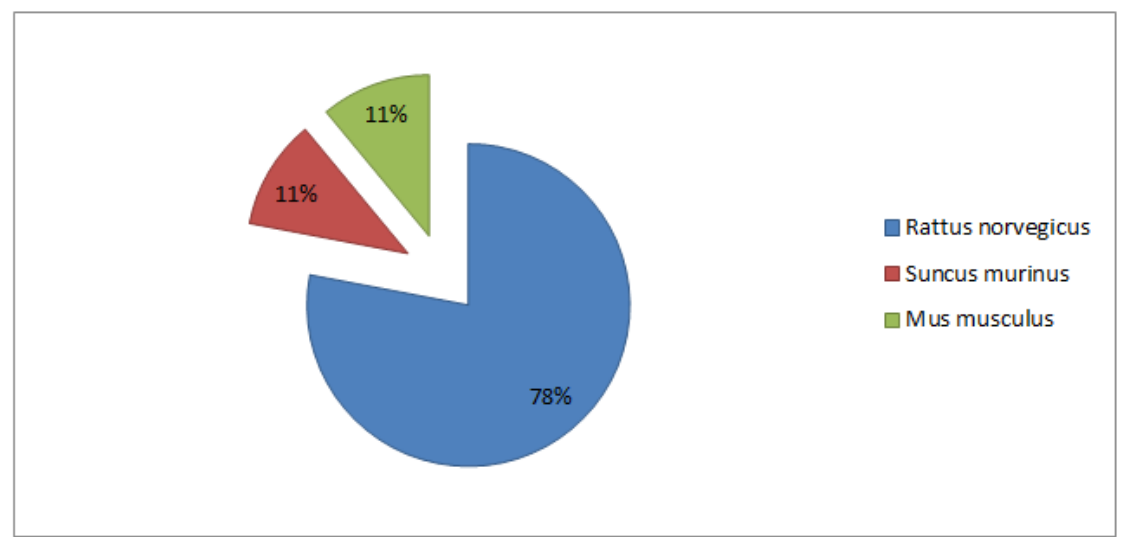

Fig-1: Identification of rat species at Sultan Hasanuddin International Airport and Antang Village

From Figure 1 regarding the identification of mice, it can be seen that the mice caught during the study were Rattus norvegicus $(78 \%)$, Suncus murinus $(11 \%)$, and Mus musculus $(11 \%)$. The most common mice were mice with 30 male sex $(81 \%)$ and female-only $7(19 \%)$.

\section{The existence of Trash}

Table-1: Observation Results of the Existence of Waste in the Rat Trap Installation Location

\begin{tabular}{|c|c|c|c|c|c|c|c|c|c|}
\hline \multirow{2}{*}{\multicolumn{2}{|c|}{ Environmental Conditions }} & \multicolumn{2}{|c|}{ Frequency } & \multicolumn{2}{|c|}{$\begin{array}{c}\text { Number of Rats } \\
\text { Trapped }\end{array}$} & \multicolumn{2}{|c|}{$\begin{array}{l}\text { Number of } \\
\text { mice that are } \\
\text { positive } \\
\text { endoparasites }\end{array}$} & \multicolumn{2}{|c|}{$\begin{array}{c}\text { Number of } \\
\text { Rats that were } \\
\text { Positive } \\
\text { Ectoparasites }\end{array}$} \\
\hline & & $\mathbf{n}$ & $\%$ & $\mathbf{n}$ & $\%$ & n & $\%$ & $\mathbf{n}$ & $\%$ \\
\hline \multirow{3}{*}{$\begin{array}{l}\text { The existence } \\
\text { of Trash Can }\end{array}$} & There is & 33 & 33 & 17 & 63 & 16 & 59 & 16 & 62 \\
\hline & There is no & 77 & 77 & 10 & 37 & 6 & 22 & 9 & 8 \\
\hline & Total & 100 & 100 & 27 & 100 & 22 & 81 & 27 & 100 \\
\hline
\end{tabular}

From table 1 regarding the observation of the presence of waste, it is known that $33(33 \%)$ locations have trash bins within a radius of 10 meters, $17(63 \%)$ traps are positive there are mice and $16(94 \%)$ mice that are trapped positively have endoparasites in the form of adult worms, larvae and eggs, 3 of them were positive Ectoparasites and 42 rat trapping locations where the environment did not have a trash bin 


\section{Identification of Ectoparasites}

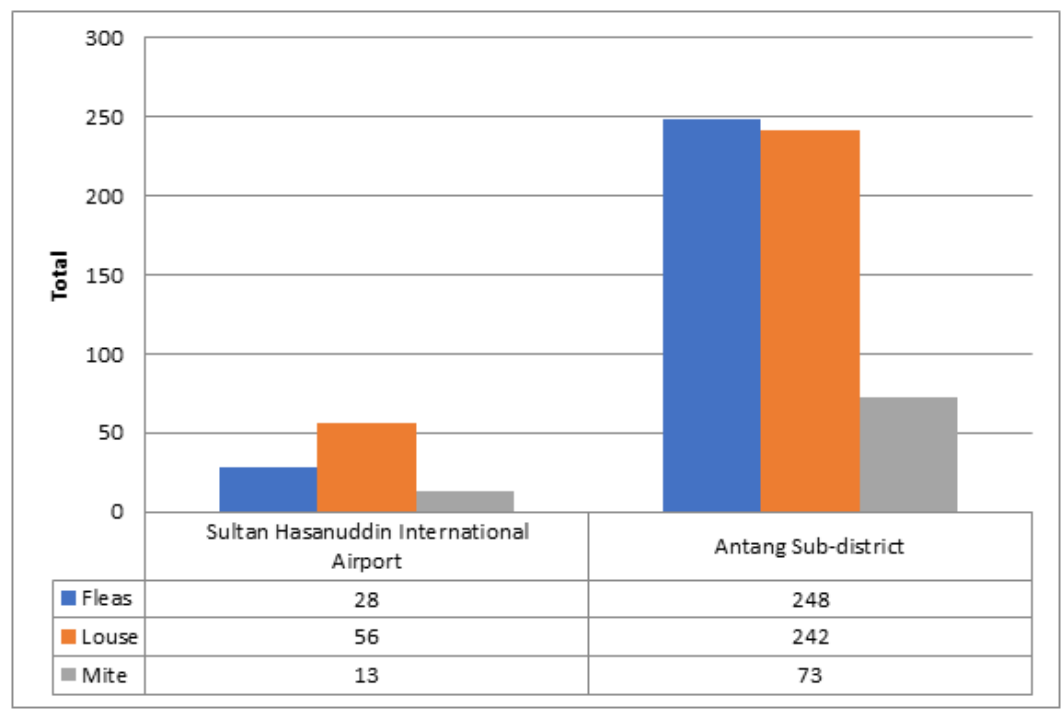

Fig-2: Results of ectoparasite examination in rats at Sultan Hasanuddin International Airport and Antang Village

Figure 2 shows the examination and identification of ectoparasites carried out in this study to obtain the results of 3 species of ectoparasites that infest the mice caught namely fleas, ticks, and mites. The number of infected mice shows a high figure illustrated by the value of the flea index 1 for Sultan Hasanuddin International Airport and 3.5 for Antang Village.

\section{Endoparasites identification}

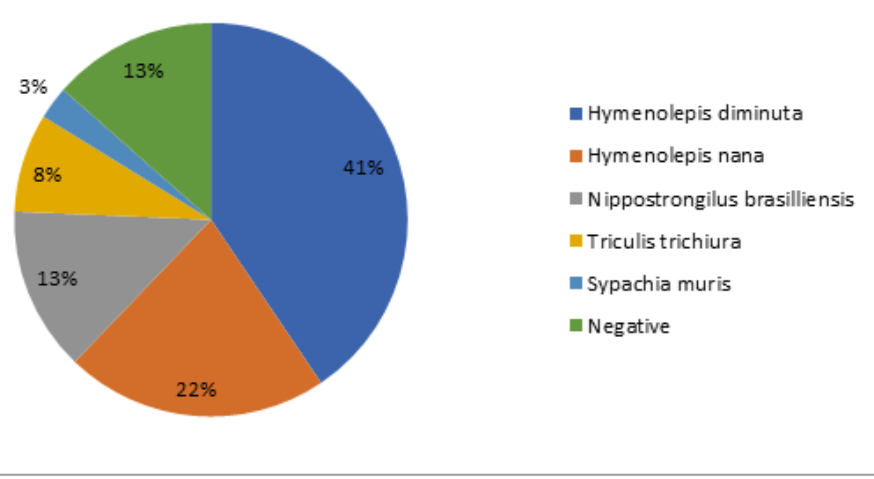

Fig-3: Endoparasite examination results in rats at Sultan Hasanuddin International Airport and Antang Village

Figure 3 shows the results of identification of endoparasites in the form of adult worms, larvae, and eggs in 37 trapped rats, there were 30 mice found 3 species of endoparasites from the Nematoda subclass namely Nippostrongylus Brasiliense, Sypachia Muris and Tricuris triciura and 2 species from the subclass Cestoda namely Hymenolepis minimuta and Nippostrongylus brasilliensis, Sypachia muris and Tricuris triciura and 2 species from the sub class Cestoda namely Hymenolepis diminuta and Hymenolepis nana.

Relationship between the existence of Waste and Endoparasites in Rats

Table-2: Relationship of the existence of waste to the presence of endoparasites and ectoparasites in mice

\begin{tabular}{|c|c|c|c|c|c|c|c|c|c|}
\hline \multicolumn{2}{|c|}{ Environmental Conditions } & \multicolumn{2}{|c|}{$\begin{array}{c}\text { Endoparasites in } \\
\text { mice }\end{array}$} & \multirow[t]{2}{*}{ Total } & \multirow[t]{2}{*}{$p$} & \multicolumn{2}{|c|}{$\begin{array}{c}\text { Ectoparasites in } \\
\text { Rats }\end{array}$} & \multirow[t]{2}{*}{ Total } & \multirow[t]{2}{*}{$p$} \\
\hline \multirow{3}{*}{$\begin{array}{c}\text { The existence of } \\
\text { garbage }\end{array}$} & & Positive & Negative & & & Positive & Negative & & \\
\hline & There is & 16 & 1 & 17 & \multirow[t]{3}{*}{0,047} & 16 & 1 & 17 & \multirow[t]{3}{*}{0,693} \\
\hline & There is no & 6 & 4 & 10 & & 9 & 1 & 10 & \\
\hline \multicolumn{2}{|c|}{ Total } & 22 & 5 & 27 & & 25 & 2 & 27 & \\
\hline
\end{tabular}


Table 2 shows the relationship between the presence of waste with the presence of endoparasites in rats tested statistically using the Fisher exact test shows that the relationship between the presence of open waste with the presence of endoparasites in mice with a value $=0.047<0.05$, which means the test results are significant.

\section{Relationship between the existence of Waste and Ectoparasites in Rats}

From table 2 it is known that environmental conditions namely the presence of waste that affects the presence of ectoparasites in rats tested statistically using the Fisher exact test shows that the relationship of the presence of waste with the presence of ectoparasites in mice with a value $=0.693>0.05$ which means the test results are not significant.

\section{DISCUSSION}

This study shows that environmental conditions influence the presence of ectoparasites and endoparasites in mice. The presence of waste shows a significant relationship with the presence of endoparasites and does not show a significant relationship with the presence of ectoparasites in mice.

From the identification of mice at Sultan Hasanuddin International Airport, eight out of ten rats caught were Rattus norvegicus (sewer rat) $(80 \%)$ and two other rats $(20 \%)$ were Suncus murinus (shaved). In Antang kelurahan, trapped mice were more diverse, namely 21 Rattus norvegicus $(78 \%)$, Suncus murinus as much as four (15\%), and Mus musculus two (7\%). From this presentation, it can be seen that Rattus norvegicus has the most presentations in this study. Rattus Norvegicus is an important reservoir in the spread of Murine typhus.

A study conducted by Rezeki [17] showed that the presence of rats in and around buildings or houses has a 38.7 times greater risk of Murine typhus in residential areas because it carries more fleas than other types of mice. According to the research of Pui et al. [26], Rattus norvegicus mice are a group of large rats that tend to be peridomestic (outside the home or building) and terrestrial activities, so that their range is wider. Adult male mice are more at risk of being infected with ectoparasites and endoparasites because the movement patterns of these mice are greater than those of female and young or juvenile mice [6].

Worms, especially the species Hymenolepis diminuta and Hymenolepis nana, attack mostly in sewer mice (Ratus norvegicus) and house mice (Rattus diardi). Whereas sypachia muris attacks small mice (Mus musculus) [18]. Mice usually get rid of stool in standing water. Through this pool of water, adult worms, worm larvae, and eggs will enter the human body [19].

Some types of zoonotic worms are known to be able to adapt to tropical environments with high rainfall. Currently, cases of helminthiasis are predicted to increase with the effects of global warming and poor physical, chemical and biological environmental conditions, both due to human activities, such as garbage, sewers, and puddles and natural events, such as natural disasters such as floods, earthquakes, and others [20].

Locations that have an open trash can have the potential to become rat habitat. Like the research conducted by Priyanto et al. [21] about risk factors that influence the incidence of worms and Murine typhus in 2015 in Demak Regency which explains that the presence of garbage in buildings and the environment outside the building will affect the incidence of Murine typhus and worms with rat agents. Therefore, it is suggested to the community and workers to close the trash can in the surrounding environment. These conditions can affect the development of mice in these locations.

The picture of worm infection in mice is influenced by several things namely the type of rat, the pattern of infection, the number of worms based on age, and gender. Based on infection patterns the percentage of single infections in R. norvegicus and Mus musculus is $80 \%$ and $20 \%$. Hymenolepis diminuta is the most common worm that infects mice. This is because H. diminuta worms are found in large numbers. Large amounts will affect the absorption of food juices so high that it is difficult for other worms to compete. This is the same as research conducted by Setyaningrum [4] that $91 \%$ of worms that infect mice are single infections, whereas mixed infections are only $10 \%$. Mixed infections cause a very high transmission potential because mice can spread disease to mice and humans.

Examination and identification of ectoparasites conducted in this study found that there were three species of ectoparasites that infested the mice caught, fleas, mites, and mites. The number of infected mice is illustrated by the value of the flea index 1 for Sultan Hasanuddin International Airport and 3.5 for Antang Village. Regulation of the Minister of Health of the Republic of Indonesia Number 50 of 2017 states that for the fleas index of an area it is said to be vigilant against transmission of Murine typhus if $30 \%$ of mice are infected with fleas and the general fleas index $>2$ while the specific fleas index $>1$. Xenopsylla cheopis fleas play a vector for Pes, Murine typhus, and also acts as an internal host for the Hymenolepis diminuta and nana worms [22]. 
Rahdar et al. [1] also mentioned in their research that ectoparasitic arthropods and their host rodents play an important role in the transmission of zoonotic diseases such as arbovirus, streptococcal infections, epidemics, leptospirosis tularemia and spirochaetosis in humans and animals.

Information on biometeorological correlations and the presence of ectoparasites in rats from Sultan Hasanuddin Airport and Antang Village has never been available, so in order to tackle and control rat ectoparasites that are harmful to humans, such as the bubonic plague vector, X. cheopis and S. cognatus, it is necessary to study biometeorology and ectoparasite bionomics at the study site.

Environmental conditions that affect the presence of mice with endoparasite identification results in rats that were statistically tested using Fisher exact test showed that the relationship between the presence of open waste with the presence of endoparasites in mice with a value $=0.047<0.05$, which means the test results are significant. Research conducted by Auliah [23] explains that the presence of open rubbish around the house has a greater risk for disease transmission by rats than there is no garbage. In addition, the condition of dominant vegetation and predators around the capture location is also one of the factors that support the presence of mice[24].

The existence of trash cans is an environmental factor that can influence the presence of disease vectors, especially environmental-based diseases. Worm disease is a disease originating from worms carried by mice. Rats are animals that are the main reservoir of endoparasites. Rats can live in dirty areas. The existence of trash can with an open condition will make it easier for rats to nest around the environment.

According to Syamsuar et al. [25] that the phenomenon of one host (rat) found various types of ectoparasites at the same time is known as polyparasitism. Parasitism, like this, is usually caused by an existing host environment compatible with ectoparasites. For example environmental conditions that are dirty and allow ectoparasites to breed.

According to Zain [20], poor sanitation in settlements has the potential to have a large number of rats, so that people who are active in water are at risk of contracting lmurine thypus and PES from fleas whose habitats are in moist areas. While the results of the study Mulyono et al. [24] in the city of Semarang, Central Java showed that where Murine typhus cases generally live there are puddles of water from household waste or rainwater or stagnant waterways.

\section{CONCLUSION}

The dominant type of rat caught is Rattus norvegicus. in this study, there were ectoparasites of Xenopsylla cheopis and endoparasites of the zoonotic nematode and Cestoda subclass which increased the risk of infection in humans. The presence of waste shows a significant relationship with the presence of endoparasites and does not show a significant relationship with the presence of ectoparasites in mice. For employees and community workers to always be careful and always maintain the cleanliness of the surrounding environment and maintain the cleanliness of the environment, especially locations that are found in mice so as not to spread the disease.

\section{REFERENCES}

1. Rahdar, M., Vazirianzadeh, B., Rointan, E. S., \& Amraei, K. (2015). Identification of collected ectoparasites of rodents in the west of Khuzestan Province (Ahvaz and Hovizeh), southwest of Iran. Asian Pacific Journal of Tropical Disease, 5(8), 627-631.

2. Marbawati, D., \& Pramestuti, N. (2017). Leptospirosis: New Emerging Disease in Sukoharjo District. KEMAS: Jurnal Kesehatan Masyarakat, 13(2), 230-238.

3. Saul, M. C., Philip, V. M., Reinholdt, L. G., \& Chesler, E. J. (2019). High-diversity mouse populations for complex traits. Trends in Genetics, 35(7), 501-514.

4. Setyaningrum, A. D. (2016). Jenis tikus dan endoparasit cacing dalam usus tikus di Pasar Rasamala Kelurahan Srondol Wetan Kecamatan Banyumanik Kota Semarang. Jurnal Kesehatan Masyarakat (e-Journal), 4(3), 50-59.

5. Tattersall, F. H., Nowell, F., \& Smith, R. H. (1994). A review of the endoparasites of wild house mice Mus domesticus. Mammal Review, 24(2), 61-71.

6. Simões, R. O., Júnior, A. M., Olifiers, N., Garcia, J. S., Bertolino, A. V. F., \& Luque, J. L. (2014). A longitudinal study of Angiostrongylus cantonensis in an urban population of Rattus norvegicus in Brazil: the influences of seasonality and host features on the pattern of infection. Parasites \& Vectors, 7(1), 100.

7. Allymehr, M., Tavassoli, M., Manoochehri, M. H., \& Ardavan, D. (2012). Ectoparasites and gastrointestinal helminths of house mice (Mus musculus) from poultry houses in northwest Iran. Comparative Parasitology, 79(2), 283-287.

8. Ishak, H. (2018). Pengendalian vektor. Makassar : Masagena press.

9. Fagir, D. M., \& Rayah, E. (2009). Parasites Of The Nile At In Rural And Urban Regions Of Sudan. Integrative Zoologi, 4(4):179-187. 
10. Pakdel, N., Naem, S., Rezaei, F., \& Chalehchaleh, A. A. (2013). A survey on helminthic infection in mice (Mus musculus) and rats (Rattus norvegicus and Rattus rattus) in Kermanshah, Iran. In Veterinary Research Forum (Vol. 4, No. 2, p. 105). Faculty of Veterinary Medicine, Urmia University, Urmia, Iran.

11. Kemenkes, R. I. (2014). Pusat data dan informasi kementerian kesehatan RI. Jakarta: infodatin.

12. Priyanto, D. (2012). Identifikasi Parasit Pada Tikus Di Berbagai Habitat Di Kabupaten Banjarnegara. Jurnal Kesehatan Masyarakat, 4(3):51-70.

13. Pramestuti, N., \& Widiastuti, D. (2015). Infection Of Helminth Eggs On House Rats (Rattus tanezumi) In Human Residential Area. Jurnal Epidemiologi dan Penyakit Bersumber Binatang, 5(3):121-125.

14. Narethong, H. (2020). Environmental Governance: Urban Waste Management Model. Journal La Lifesci, 1(2), 3236 .

15. Syamsuar., Daud A., Maria I.L. \& Hatta M. (2018). Environmental Health Risk Assessment in Flood Prone Area; Case Study in Wajo District. International Journal of Science and Healthcare Research, 3(4):9-16.

16. Puskesmas, A. (2018). Profil Puskesmas Antang Tahun 2018. Makassar : Puskesmas Antang.

17. Rezeki, D.S.S. (2005). Faktor Risiko Lingkungan Yang Berpengaruh Terhadap Kejadian Leptospirosis Berat (Thesis). Semarang: Universitas Diponegoro.

18. Tutstsintaiyn, R. (2013). Pemeriksaan Cacing Endoparasit Pada Tikus (Rattus Spp.) Di Desa Citereup Kecamatan Dayeuh Kolot, Kabupaten Bandung, Jawa Barat. Balaba, 9(2):47-52.

19. Wynwood, S.J., Graham, G.C., Weier S.L., Collet T.A., Mckay, D.B., \& Craig, S.B. (2014). Leptospirosis From Water Sources. Pathogens And Global Health, 108(7):334-338.

20. Zain, S.N.M., Behnke J.M., \& Lewis J.W. (2012). Helminth Communities From Two Urban Rat Populations In Kuala Lumpur, Malaysia. Parasites and Vectors, 5(47):1-23.

21. Priyanto, A. (2008). faktor-faktor risiko yang berpengaruh terhadap kejadian leptospirosis (Studi Kasus di Kabupaten Demak). Jurnal Epidemiologi.

22. Raharjo, J., \& Ramadhani, T. (2012). Studi Kepadatan Tikus dan Ektoparasit (Fleas) Pada Daerah Fokus dan Bekas Pes. In Prosiding Seminar Nasional Kesehatan Jurusan Kesehatan Masyarakat FKIK UNSOED.

23. Auliya, R. (2014). Hubungan antara strata PHBS tatanan rumah tangga dan sanitasi rumah dengan kejadian leptospirosis. Unnes Journal of Public Health, 3(3).

24. Mulyono, A., Agustina, M., Litbangkes, B., \& Yuliadi, B. (2019). Indeks keragaman ektoparasit pada tikus rumah Rattus tanezumi Temminck, 1844 dan TIKUS POLINESIA R. exulans (Peal, 1848) DI daerah enzootik pes lereng gunung merapi, jawa tengah.

25. Manyullei, S., Natsir, M. F., \& Batkunda, A. (2020). Identification of Rat Density and Ectoparasites in Seaport Area of Manokwari, Papua Province. Open Access Macedonian Journal of Medical Sciences, 8(E), 204-208.

26. Pui, C. F., Bilung, L. M., Apun, K., \& Su'ut, L. (2017). Diversity of Leptospira spp. in rats and environment from urban areas of Sarawak, Malaysia. Journal of tropical medicine, 2017. 